\title{
THE STUDY OF FARMERS' ECONOMIC ABILITIES IN PALM PLANTATION IN RURAL REGENCY OF MUARO JAMBI
}

\author{
Malik Adlaida*, Fitri Yanuar, Nainggolan Saidin \\ University of Faperta, Jambi, Indonesia \\ *E-mail: ida adlaidamalik@yahoo.com
}

\begin{abstract}
This research aims to Analyze household income capability to finance household needs and how to improve household income capability. The research was conducted in Muaro Jambi Regency in plasma farmers and self-help farmers. The research was conducted by survey where the sample was taken based on the representative representation of the phenomenon of the population. Sampling used is a multi stage sampling of sub-districts and villages. The sample size are 60 farmers consist of 30 Plasma Farmers and 30 Swadaya Farmers. The result of the research shows that 1) There is a significant difference between the average household income of Plasma Farmers with the average income of households of Swadaya Farmers, 2) There is a significant difference between the average cost of household needs of Plasma Farmers with the average home needs Ladder of Swadaya Farmers. 3) There is a significant difference between the level of household income capability of Plasma Farmers and Self-Helpers. Household income level of Plasma Farmers who are able to finance their household needs is about 95\% relatively higher than Swadaya farmers about $87 \%$, 4) The level of household income capability of Plasma Farmers and Self-Helpers who can not afford to finance their household needs can be improved through the application of crop pattern Inbetween palm-rice/corn-pineapple/banana-chili, and through the use of leisure time used for productive work each become 139.6 percent and 144.3 percent thus all farmers will be able to finance their household needs.
\end{abstract}

\section{KEY WORDS}

Income, economic ability, income, stage options.

Now Palm has become Indonesia's main export commodity and has been a major source of livelihood for millions of families. People's palm covers 83 percent of the total area of oil palm plantations in Indonesia with production volume reaching 68 percent of total palm production in Indonesia (DITJENBUN, 2016). Now Jambi Province is the third largest producer of palm oil after South Sumatra and North Sumatra. In terms of production of Cruide Palm Oil [CPO], 87 percent is sourced from people's palm with an average plantation area of 3.85 hectares per farmer. Oil palm plantations in this area are growing so that the remaining natural forests are getting smaller, people's palm oil estimated has reached about 11.5 percent from Jambi Province (Anonymous, 2009).

Oil palm plantations in Jambi Province have a very strategic role as the province is the main producer of natural palm oil in Indonesia with a total area of about 490,346 hectares in 2003 and total production of 423,752 tons or 21.78 percent of Indonesia's palm oil production, and in 2016 Increased to approximately 526,174 hectares and total production of 453,365 tons or $23.71 \%$ of Indonesia's palm production. Contribution of palm to Product of Gross Regional Domestic (PDRB) Jambi equal to Rp 1,347 million or 36,56 percent from total export of GRDP without oil and gas Jambi Region. The export volume of Jambi's palm oil is 427,37 thousand tons which gives the country's foreign exchange input amounting to US $\$ 18.2$ million or 18.72 percent of the export of Jambi's plantation commodities. Besides oil palm plantations as a source of income and livelihood of about 260 thousand households and 20 thousand employees of plantation companies and processing industries of TBS is about 1.15 million people or 37.6 percent of the total population of Jambi Province (Central Bureau of Statistics Jambi Province, 2017). 
The development of smallholder palm oil plantations in Jambi Province from various government projects namely the Nucleus Company (PIR) project, the Project Implementation Unit (UPP) and the partial relief project for 25 years (1977/1978 to 2016) was recorded to reach 224,712 ha or about $8,988 \mathrm{Ha}$ per year. Since 1991 the government no longer develops plantations through PIR and UPP because there are other problems that some farmers cannot afford to pay off their credit and the quality of the oil palm is low but the palm oil development is still done by the government through the aid (Directorate General of Plantation Development, 2017).

In 2003-2017 the provincial and district governments in Jambi Province rejuvenated 1,248 hectares of community palm plantations through a state aid project, but in fact in 2017 the average palm oil productivity of 11.68 tons per year is relatively more Low compared to the productivity of oil palm plantations of the State of approximately 15.16 tons of TBS per hectare per year (Jambi Provincial Plantation Office, 2017).

One of the goals of rejuvenation of oil palm plantation is replacing old / damaged plants with superior clones of young who have high productivity. Rejuvenation of oil palm by farmers takes about six years to start producing. Therefore, farmers do not earn income from palm oil farming while the household needs continue so that there is a possibility of household income of farmers unable to finance their household needs. With this condition raises the question of how much is the level of income ability of households to finance their household needs before and during the reforestation of oil palm plantations and what are the options to increase farmers' household income?

From the fact that the condition of the palm oil plantation of low productivity of palm oil, the extent of the old / damaged plantation area and the hope of accelerating the rejuvenation of the people's palm oil plantation, it can be concluded that the main problem is "how to increase farmers' household income ability to finance their household needs with some basic questions as follows:

1. Is there a significant difference between household income, household expenses and household income capability to finance household needs Smallholders with self-help Farmers?

2. What is the option to increase the level of income ability of households of oil palm farmers?

In general, research aims to:

1. Analyze the difference between household income, household expenses and household income capability to finance household needs Smallholders with self-help farmers;

2. Analyze the option to increase the income level of household income of Palm farmers.

\section{FRAMEWORK OF STUDY}

Theoretical basis. Increase in farmers' income in the short term can be done through the use of gawangan between the palm by planting intercrops. Upgrading of oil palm growers can be achieved through palm oil reforestation along with land use among palm crops through integrated farming patterns (Tjasadihardja et al., 1995). The basic concept of the household economy is that the decisions for the production and consumption of farm households are related to each other (Becker, 1965, Chayanov, 1966 and Ellis, 1998). This study looks at the economic behavior of farm households to finance their household needs independently.

Efforts to improve household income levels can be done by increasing household income of farmers or reducing the cost of farmers' household needs. Increase in household income of farmers can be done on the pattern of oil palm crops through increased production of palm oil and increased productivity while the expansion of palm oil is relatively difficult to implement due to limited land owned by farmers. Increased income of other farming can be done on the land of yard business. Increased income outside the farm through the use of leisure time to work on other farmers' farming land, trading, or as employers or civil servants. 
Household economic theory with respect to time allocation, leisure time usage, production and consumption are household decisions, while the allocation of spare time into working time in business activities will increase income. Activities in households for final (final) final goods that do not provide income and are known as Z - good. In addition, households have the opportunity to sell time to the labor market. Therefore, households should be able to allocate time optimally for production, work and leisure activities with time constraints, income, and certain production functions (Becker, 1965).

The concept of time allocation is also put forward by Becker (1965) which states that in a household the allocation of time is divided into three: (1) time to produce $Z$ goods, (2) time to work as wage or wage; Leisure time in the family. Maximum utility in a household is limited by three constraints: (1) production function, (2) minimum required level of income, and (3) maximum amount of available working time.

Spare time (WI) is part of the available time that is not used for productive activities in farming or outside farming. Spare time is used to seek additional income for a household or to sell it in the labor market, or to consume the free time to relax (Bakri, 2003 in Zahri, 2003). The view on leisure leisure is found to vary, between work at home or other activities often difficult to distinguish by leisure, and this is one of criticisms of Becker's time allocation theory (Granon, 1997 in Hardi, 1990).

\section{METHODS OF RESEARCH}

Approach Method. The foundation of the research philosophy of 'Farmers Income Ability Analysis in Meeting the Cost of Household Rural Needs in Muaro Jambi District is a philosophy of positivism. According to Ethridge (1995), the philosophy of positivism (logical positivism) developed from physical science, and in economics involves the study of community values that stress the positive knowledge with measurement and quantification of data, and tends to make facts and theories as the source of the hypothesis. The approach method used in this research is developed by deductive and inductive approach method. The sequence of approaches is identifying problems, analyzing data and information, and explaining data and drawing conclusions.

Sampling Techniques and Data Collection. The research was conducted by survey where the sample was taken based on the consideration of the representation of the characteristics of population phenomenon. In analyzing field research data supported by quantitative and qualitative data, to control information that is qualitative required quantitative data information while to clarify quantitative data required qualitative data. Sampling used is a multi stage sampling of sub-districts and villages.

From each village a random sample of 60 samples of farmers from selected sample villages was collected. The samples of plasma farmers and self-help farmers were determined based on the proportional framework of the sample of farmers, so there were 30 plasma farmers and 30 self-help farmers, thus the total sample was 60 farmers. Data analysis used is descriptive analysis and multiple linear regression analysis.

\section{RESULTS AND DISCUSSION}

Farmer's Characteristics. The plasma farmers had an average age of 47.6 years, the number of family members of 3 - 4 people, the experience of the palm oil cultivation of 22.8 years of land ownership of $4.6 \mathrm{Ha}$. While self-employed farmers have an average age of 43.1 years, the number of family members $4-5$ people, experience of palm oil 21.4 years, land area of $3.15 \mathrm{Ha}$. Adoption of palm cultivation technology as recommended. The plasma farmers have a value for rejuvenation of Rp. 26.269 .666 or $61.02 \%$. The cost of seedlings is $48.98 \%, 95.49 \%$ outside of family labor costs, $29.58 \%$ for palm oil maintenance. While selfhelp farmers rejuvenation costs of Rp. 16.783 .222 or $39.98 \%$. The cost of seedlings is $51.02 \%$, the labor cost of the family is $4.51 \%$, the maintenance cost is $70.42 \%$. 
Household Income. The household income of the farmers is sourced from palm oil, other farm income and income from outside farming. The income of farm households from the source of income of palm oil, other farming and outside farming can be seen in Table 1.

Table 1 - Average Revenue of Oil Palm Farmers, Year 2017

\begin{tabular}{cccccccc}
\hline \multirow{2}{*}{ No } & \multirow{2}{*}{ Revenue Source } & \multicolumn{7}{c}{ Household Income } \\
\cline { 2 - 7 } & & Smallholders & $\%$ & Self-help farmers & $\%$ & Average & $\%$ \\
\hline 1 & Palm Farming & 46.967 .583 & 93,36 & 37.589 .364 & 91,77 & 42.278 .474 & 92,65 \\
2 & Other farms & 454.646 & 0,90 & 499.883 & 1,22 & 477.265 & 1,05 \\
3 & Outside farm & 2.888 .000 & 5,74 & 2.869 .000 & 7,00 & 2.878 .500 & 6,31 \\
\hline & Amount & 50.310 .229 & 100 & 40.958 .247 & 100 & 45.634 .239 & 100 \\
\hline
\end{tabular}

Table 1 shows that the average household income of smallholders is around Rp. $50,310,229$ per year and self-help Farmers around Rp. 40,958,247 per year, the majority of household income is obtained from oil palm farming, plasma farmers around $93.36 \%$ and self-employed farmers around $91.77 \%$. The result of statistical analysis of test of middle value of significance at $95 \%$ confidence level. This means that household income of smallholders is significantly different from household income. Self-employed farmers or average household incomes Smallholders are $158.31 \%$ above the average household incomes.

In line with the Lestari Eka research, E. (2015) which states that the average income of oil palm farmers is higher than the average income of oil palm farmers self-help. The result of independent sample test shows that the income of plasma farmers is Rp.40.735.794 per hectare per year while the average income of self-farmers is 26.312 .996 per two hectare per year.

Cost of Farmers Household Needs. The cost of the household needs of farmers consists of the cost of food consumption and other costs. The cost of food consumption includes the cost to buy rice, side dishes, salt, sugar, coffee / tea, edible oil, kerosene and fruits. Other cost needs include fees for children's education, health, clothing, soap / toothpaste, home improvement, purchase of household furniture, arisan / recreation, social / religious and building taxes. The details of the average cost of household needs of oil palm farmers can be seen Table 2.

Table 2 shows that the average household needs of smallholders is around Rp $43,430,648$ per year with the composition for food consumption $(49.35 \%)$ and other needs $51.41 \%$. Average household needs Self-help farmers around Rp. 42,460,826 per year with the composition for the cost of food consumption (50.65\%) and other necessities $(48.59 \%)$. The result of statistical analysis of the mean value test is significant at $95 \%$ confidence level. This means that the average household needs of smallholders is significantly different from the average household needs. Self-farmers or in other words the average cost of household needs Plastic farmers are $112 \%$ above the average cost of household needs Self-help farmers.

Jaenuri's research, H (2016) household consumption, especially for food, will continue to increase food consumption in line with increasing income, but to some extent the addition of income no longer causes the increase in the amount of food consumed. If the quantity of needs has been met, then people will usually attach importance to quality or switch to the fulfillment of non-food needs.

Ability of Household Income. The ability of household income is the level of farmers' household income ability to finance their household needs. The level of income ability of households to finance household needs can be seen Table 3.

Table 3 shows that the level of household income capability of smallholders who are able to finance household needs is about $20 \%$, while the income earning rate of self-farming Farmers can afford $0 \%$ or the overall income level of household income is about $10 \%$. From the results of statistical analysis of the mean value of middle test at $95 \%$ confidence level. This means that the level of household income capability Smallholders are significantly different from households' income earning capacity Self-help farmers, or household income 
earning capacity Plastic farmers to finance their household needs is relatively higher than the self-employed Farmer's level of ability.

Table 2 - Average Cost of Palm Oil Households by 2017

\begin{tabular}{|c|c|c|c|c|c|}
\hline \multirow{2}{*}{ No } & \multirow{2}{*}{\multicolumn{2}{|c|}{ Cost Description }} & \multicolumn{3}{|c|}{ Cost of Living Needs (Rp) } \\
\hline & & & Smallholders & Self-help farmers & Average (Rp) \\
\hline \multirow[t]{13}{*}{1} & \multicolumn{5}{|c|}{ Food Consumption Needs } \\
\hline & a. & Rice & 4.791 .110 & 5.051 .747 & 4.921 .428 \\
\hline & b. & Side dishes & 7.152.117 & 7.586 .517 & 7.369.317 \\
\hline & c. & Vegetables & 469.017 & 453.700 & 461.358 \\
\hline & d. & Sugar / salt & 610.697 & 572.607 & 591.652 \\
\hline & e. & Coffee / tea / milk & 1.208 .900 & 1.034 .323 & 1.121 .612 \\
\hline & f. & Vegetable oil & 607.200 & 612.133 & 609.667 \\
\hline & g. & Kerosene & 559.187 & 485.700 & 528.527 \\
\hline & $\mathrm{h}$. & Fruits & 551.400 & 570.600 & 561.000 \\
\hline & i. & Nuts & 112.771 & 99.938 & 106.354 \\
\hline & j. & Tubers & 127.967 & 143.550 & 135.758 \\
\hline & $\mathrm{k}$. & Spices & 1.258 .500 & 1.294 .717 & 1.276 .608 \\
\hline & \multicolumn{2}{|c|}{ Amount } & $\begin{array}{l}17.448 .866 \\
(49,35 \%)\end{array}$ & $\begin{array}{l}17.905 .532 \\
(50.65 \%)\end{array}$ & $\begin{array}{l}17.683 .281 \\
(50,02 \%)\end{array}$ \\
\hline \multirow[t]{12}{*}{2} & \multicolumn{5}{|c|}{ Other Needs } \\
\hline & a. & Child education & 3.423 .867 & 3.618 .333 & 3.521 .100 \\
\hline & b. & Health & 997.967 & 952.333 & 975.150 \\
\hline & c. & Clothes & 3.105 .667 & 3.179 .000 & 3.142 .333 \\
\hline & $\mathrm{d}$ & Soap / toothpaste & 691.233 & 591.633 & 641.433 \\
\hline & e. & Home improvement & 666.667 & 633.333 & 650.000 \\
\hline & f. & Home furnishings & 986.425 & 930.941 & 958.683 \\
\hline & g. & Social / religious events & 7.196 .460 & 5.824 .508 & 6.510 .484 \\
\hline & $\mathrm{h}$. & Property taxes & 49.496 & 35.380 & 42.438 \\
\hline & i. & Transportation & 8.864 .000 & 8.789 .833 & 8.826 .917 \\
\hline & \multicolumn{2}{|c|}{ Amount } & $\begin{array}{l}25.981 .782 \\
(51,41 \%)\end{array}$ & $\begin{array}{l}24.555 .294 \\
(48,59 \%)\end{array}$ & $\begin{array}{l}25.268 .538 \\
(50 \%)\end{array}$ \\
\hline & \multicolumn{2}{|c|}{ Amount } & 43.430 .648 & 42.460 .826 & 42.951 .819 \\
\hline
\end{tabular}

Table 3 - Farmers Household Income Rate Ability by 2017

\begin{tabular}{llllllll}
\hline \multirow{2}{*}{ No } & \multirow{2}{*}{ Level of Household Income Capability } & \multicolumn{2}{l}{ Smallholders } & \multicolumn{2}{c}{ Self-help farmers } & \multicolumn{2}{l}{ Total } \\
\cline { 3 - 7 } & Household & $\%$ & Household & $\%$ & Household & $\%$ \\
\hline 1 & Capable of $\mathrm{Kr} \geq 1$ & 6 & 20 & 0 & 0 & 6 & 10 \\
2 & Not able to $<1$ & 24 & 80 & 30 & 100 & 54 & 90 \\
\hline Amount & 30 & 100 & 30 & 100 & 60 & 100 \\
\hline
\end{tabular}

Note:

$K r=(Y t: K B) X 100 \%$

$K r=$ Ability to pay for living needs (\%)

$Y t=$ Household income (Rp / year)

$K B=$ Cost of household needs (Rp / year)

Household income level Farmers who are unable to finance their household needs are around $80 \%$ and self-help farmers are $100 \%$, all farmers who are unable to finance their household needs are farmers who are currently reforesting about $11.2 \%$. Farmers who are unable to finance their household needs are farmers who have unprofitable crops whereas, income from intercropping pattern cropping pattern and out-of-farm income is relatively low so it is not enough to finance household needs. Lack of farm household income to finance household needs by saving last year or borrowing money from families, village palm oil collectors or other farmers who will be paid from work outside the farm or after the start of palm oil production.

In contrast to Malik A's research, Murdy S, Nainggolan S (2015), the level of household income earning capacity of households that can afford households is $92.0 \%$, while the income earning rate of farmers is not yet advanced which can afford the household needs of about $74,29 \%$ or the overall level of farmers' household income capability is about $81.67 \%$. From the results of statistical analysis of the mean value of middle test at $95 \%$ confidence 
level. This means that the income level of farm household income is significantly different from the level of income ability of the farmer's household is not yet developed, or the level of income ability of the farmer's household to finance the household's need is relatively higher than the level of the farmer's ability not yet developed.

Option to Increase Household Income Capability

1. Application of Palm Selective Crop Patterns.

The effort to increase farmers' household income ability can be done through the implementation of the pattern of palm oil crops with food crops and horticulture as recommended by extension workers. Implementation of palm oil cropping pattern Smallholders and self-help farmers can still be improved by planting palm-rice / corn-banana / pineapple-chili pattern as Table 4.

Table 4 - Production and Production Potential of Palm Sela Plant

\begin{tabular}{cccccccc}
\hline No & $\begin{array}{c}\text { Types of } \\
\text { Plants }\end{array}$ & $\begin{array}{c}\text { Current } \\
\text { Production }\end{array}$ & $\begin{array}{c}\text { Production } \\
\text { Potential }\end{array}$ & $\begin{array}{c}\% \text { Of } \\
\text { potential }\end{array}$ & $\begin{array}{c}\text { Current } \\
\text { Production }\end{array}$ & $\begin{array}{c}\text { Production } \\
\text { Potential }\end{array}$ & $\begin{array}{c}\% \text { Of } \\
\text { potential }\end{array}$ \\
\hline 1 & Rice & 825 & 1.800 & 45.83 & 850 & 1.600 & 53.13 \\
2 & Corn & 320 & 900 & 35.56 & 360 & 1.000 & 36.00 \\
3 & Vegetables & 300 & 650 & 46.15 & 325 & 700 & 46.43 \\
4 & Turmeric & 150 & 450 & 33.34 & 150 & 650 & 23.08 \\
5 & Ginger & 142 & 300 & 47.33 & 160 & 325 & 49.23 \\
\hline
\end{tabular}

In Table 4 it can be explained that the average application of intercropping pattern of new plasma farmers reaches about $41.64 \%$ of the potential production pattern of recommended palm crops and self-help Farmers about $41.57 \%$ of the potential production pattern of palm oil plantations recommended that it can still increase revenue Households Smallholders are around $58.36 \%$ and self-employed farmers are $58.43 \%$ of the current farmers' current production. In contrast to research by Lestari Eka, E. (2015) stated that the percentage of agricultural income source outside of palm oil pattern is $13.36 \%$ and selffarmer is $14.11 \%$ so it can still increase household income of plasma farmers around 86.64 and Self-help farmers around $85.89 \%$.

The potential increase in income and income capability of households of oil palm farmers through the implementation of the pattern of palm oil plant in 2017 can be seen in Table 5.

Table 5 - Potential of Increasing Revenue and Income Capability of Household of Palm Farmer Through Application of Palm Selective Crop Pattern

\begin{tabular}{llccc}
\hline No & Average Household Income & Smallholders (Rp thousand) & $\begin{array}{c}\text { Self-help farmers } \\
\text { (Rp thousand) }\end{array}$ & $\begin{array}{c}\text { Average } \\
\text { (Rp thousand) }\end{array}$ \\
\hline 1 & Original revenue & 16.142 & 25.554 & 20.848 \\
2 & Potential increase & 7.635 & 9.477 & 8.556 \\
3 & Household income & 23.777 & 35.031 & 29.404 \\
4 & Increased revenue (\%) & 43.30 & 37.09 & 42.20 \\
5 & Income capability (\%) & 51.64 & 43.14 & 94.78 \\
\hline
\end{tabular}

In Table 5 it can be explained that the application of good intermediate palm-rice / pineapple / banana-chili pattern will increase household income of $47.30 \%$ and farmers around $37.30 \%$, while palm oil intercropping -good / vegetable-turmeric-ginger-kernel will increase household income capability Smallholders about $51.64 \%$ is relatively higher than the increase in household income capacity Self-employed farmers around $43.14 \%$ or overall will increase household income capability Farmers around $47.39 \%$.

2. Utilization of Spare Time to Work Productive.

The limited source of household income of farmers from on farm, off farm and nonfarm can be overcome by farmers with the utilization of spare time. The allocation of available household working time, working time for households, rest time, working time used for oil 
palm business activities, other farming, outside the farmers' farming and household livelihoods can be seen Table 6.

Table 6 - Allocation of Palm Oil Farming Working Time of 2017

\begin{tabular}{llcccccc}
\hline \multirow{2}{*}{ No } & \multirow{2}{*}{ Description } & \multicolumn{5}{c}{ Allocation of Working Time } \\
\cline { 3 - 7 } & & \multicolumn{2}{c}{ Smallholders } & \multicolumn{2}{c}{ Self-help farmers } & \multicolumn{2}{c}{ Average } \\
\cline { 3 - 7 } & Men's Day & $\%$ & Men's Day & $\%$ & Men's Day & $\%$ \\
\hline 1 & Time available & 948 & 100 & 962 & 100 & 955 & 100 \\
2 & Time for RT & 239 & 25.21 & 247 & 25.68 & 243 & 25.45 \\
3 & Time off & 280 & 29.54 & 296 & 30.77 & 288 & 30.16 \\
4 & Productive time & 265 & 27.95 & 301 & 31.29 & 283 & 29.63 \\
5 & Free time & 164 & 17.30 & 118 & 12.26 & 241 & 14.76 \\
\hline
\end{tabular}

In Table 6 it can be seen that the average working time available of smallholders and self-employed farmers is about 955 man-days (HKO) per household per year. Time allocation used for household and rest activities Self-help farmers are relatively more than plasma farmers. Time spent on productive activities Farmers are around 301 HKOs or $31.29 \%$ while smallholders are around $265 \mathrm{HKO}$ or $27.95 \%$. The result of statistical analysis of the mean value test is significant at $95 \%$ confidence level. This means productive working time allocation Self-help farmers are significantly different from the productive working time allocation Smallholders or productive working time Self-farming farmers are relatively higher than the productive working time allocation of smallholders.

The untapped leisure time for this large productive activity can actually be used to increase the income of farm households. Left untapped for productive activities Smallholders are around 164 HKOs and self-employed Farmers are around HK $\$ 118$ per year. When the spare time plasma farmers and self-help farmers are used to work productively with a certain wage rate will be obtained potential household income. Working opportunities that are available outside the most farming are for the activities of factory workers, candied traders / daily necessities of self-employed wood and stone crafts. The potential increase in income and income capability of households of oil palm farmers through the utilization of leisure time for productive activities in 2017 seen Table 7.

Table 7 - Potential Increase in Income and Profitability of Household Revenue by Oil Palm Farmers through 2015 Leisure Utilization

\begin{tabular}{llccc}
\hline No & \multicolumn{1}{c}{$\begin{array}{c}\text { Average Revenue } \\
\text { Household }\end{array}$} & $\begin{array}{c}\text { Smallholders } \\
\text { (Rp thousand) }\end{array}$ & $\begin{array}{c}\text { Self-help farmers } \\
\text { (Rp thousand) }\end{array}$ & Average (Rp thousand) \\
\hline 1 & Original revenue & 16.142 & 25.554 & 20.848 \\
2 & Potential increase & 6.330 & 7.836 & 7.083 \\
3 & Household income & 22.472 & 33.390 & 27.931 \\
4 & Increased revenue (\%) & 39.21 & 30.66 & 34.94 \\
5 & Income capability (\%) & 41.74 & 36.17 & 38.96 \\
\hline
\end{tabular}

Table 7 shows that the utilization of leisure time for productive activities will increase household income Smallholders of around $39.21 \%$ and self-employed farmers around $30.66 \%$ while the use of leisure time productive activities will increase household income capability of smallholders about $41.74 \%$ relative Higher than the increase in household income ability Self-employed farmers around $39.17 \%$ or overall average will increase farmers' household income capability by about $38.96 \%$.

Average level of household income ability Farmers who can not afford to pay for their living need about $25.71 \%$, with the increase of economic ability through the application of oil palm intercropping pattern around $43.30 \%$ and through the utilization of spare time about $39.21 \%$. If done by plasma farmers together, it will increase the household income capability of plasma farmers to about $142.5 \%$, with this increase means that plasma farmers will be able to finance their life needs because the household capability level of farmers is more than $100 \%$.

Average household income earning capacity Self-help farmers who can not afford the cost of living are around $8.0 \%$, with an increase in household income through applying the 
pattern of intercropping crops around $37.09 \%$ and through the utilization of spare time around $30.66 \%$. If undertaken by self-help farmers collectively, it will increase the household income capacity of self-farmers to about $137.4 \%$, with this increase means household income Farmers are more than $100 \%$.

\section{CONCLUSION AND RECOMMENDATIONS}

From the analysis of farmers' household income capability in financing their household needs, the following conclusions can be drawn:

There is a significant difference between the average household income of smallholders and the average household income of self-employed farmers;

There is a significant difference between the average cost of household needs Smallholders with average household needs Self-help farmers. Being 112.5 percent above the average cost of household needs Self-help farmers;

There is a significant difference between the level of household income capability of smallholders and non-farmers. Household income level Plastic farmers who are able to finance their household needs are about $95 \%$ relatively higher than self-employed farmers about $87 \%$;

The level of household income capability Smallholders and non-farmers who can not afford to finance their household needs can be improved through the implementation of the pattern of oil palm-rice / pineapple / banana-chili plants, and through the utilization of leisure time used for productive work, Respectively to about 139.6 percent and 144.3 percent thus all farmers will be able to finance their household needs.

In order to empower the household economics of sustainable palm oil farmers, it is suggested to need a policy on guidance and counseling from related institutions with efforts to improve the technical capability of oil palm farmers and the provision of financial aid and credit funds to motivate farmers to rejuvenate their oil palm using superior clones.

\section{REFERENCES}

1. Anonymous, 2009. Profile of Commodity Unngulan Plantation of Jambi Province.

2. Regional Plantation Office of Jambi Province, Jambi.

3. Central Bureau of Statistics, 2017. Jambi in Figures. BPS First Level Region of Jambi.

4. Provincial Plantation Office of Jambi Province, 2016. Plantation Statistics. Disbun Jambi.

5. Regional Plantation Office of Jambi Province, 2017. Annual Report. Disbun Jambi.

6. Directorate General of Plantation Development, 2017. Indonesian Plantation Statistics Data. Ministry of Agriculture, Jakarta.

7. Ellis. F, 1998. Peasant Economics, Farm Households and Agrarian Development. Cambridge University Press.

8. Jaenuri, Habib. 2016. Analysis of Expenditure Allocation of Household Consumption of Oil Palm Farmers in Muara Tabir Sub-district of Tebo District. Thesis, University of Jambi.

9. Lestari Eka, E. 2015. Comparative Study of Smallholder Plasma Palm Oil Plantations and Self-Supporting Patterns in Facing RSPO Certification (Case Study of Bukit Lembuh Village Subur Pelalawan Regency of Riau Province). Thesis, University of Riau.

10. Malik Adlaida. 2015. Assessment of Farmers Economic Capacity in Rubber Garden Rejuvenation in Muaro Jambi Regency. University of Jambi. Jambi.

11. Tjasadihardja. A., 1995. Effort to Increase Farmer's Income through Rejuvenation of Palm Self-supporting. Warta Pusat Penelitian Sawit. Vol. 14 (3): 147-158.

12. Authority. G., 1997. Alternative Study of Inland Crops and Oil Palm Plantations. Proceeding Appreciation of Technology for Increasing Productivity of Land of Palm Plantation Medan.

(C) 2017 by the authors. Licensee RJOAS, Orel, Russia. This article is an open access article distributed under the terms and conditions of the Creative Commons Attribution (CC BY) license: http://creativecommons.org/licenses/by/4.0/ 